\title{
Characterization of Pratylenchus crenatus and P. neglectus (Nematoda: Pratylenchidae) associated with wheat crop
}

\author{
S. KUMARI
}

\begin{abstract}
Division of Crop Protection and Plant Health, Crop Research Institute, Drnovská 507/73, Ruzyně, 16106 Prague 6, Czech Republic, E-mail: kumari@vurv.cz
\end{abstract}

\section{Article info}

Received November 10, 2014 Accepted July 7, 2015

\begin{abstract}
Summary
The distribution of Pratylenchus species associated with wheat crops was investigated in Bohemian region of the Czech Republic. In total twelve localities were sampled. The populations were identified based on morphology and morphometrics, and further characterised based on sequences of the rDNA D2/D3 region and 18S gene. Pratylenchus crenatus was present in two localities and $P$. neglectus in five localities. At one locality both species were detected. Sequence analysis of $18 \mathrm{~S}$ and D2/D3 region of three populations of $P$. crenatus reveal no variation while five populations of $P$. neglectus differ by 0 to $0.14 \%$ (18S) and 0.17 to $0.50 \%$ (D2/D3).
\end{abstract}

Keywords: Pratylenchus crenatus; Pratylenchus neglectus; PCR; ribosomal DNA; sequencing; nematode

\section{Introduction}

Root-lesion nematodes (RLN) of the genus Pratylenchus Filipjev, 1936 are migratory endoparasites of agricultural crops, considered among the most widespread and important nematode parasites in a variety of crops throughout the world (Castillo \& Vovlas, 2007). The RLN rank third only to root-knot and cyst nematodes as having the greatest impact on crops worldwide (Castillo \& Volvas, 2007; Jones et al., 2013). RLN are also a major limiting factor for cereal crop production throughout the world. Eight species of the genus Pratylenchus infest small grains (Rivoal \& Cook, 1993; Nicol et al., 2004). Among them, P. thornei Sher and Allen, 1953, P. neglectus (Rensch, 1924) Filipjev and Schuurmans Stekhoven, 1941, P. penetrans (Cobb, 1971) Filipjev and Schuurmans Stekhoven, 1941 and $P$. crenatus Loof, 1960 have a worldwide distribution and can cause substantial yield losses (Taylor et al., 1999; Nicol et al., 2004).

RLN hatch from the egg as a second-stage juvenile and starts feeding on the plant. They feed, molt and reproduce primarily within the plant tissue. All motile stages are capable of feeding from the plant and they are able to move into the soil in search of new roots to invade. After rupturing the epidermis they enter the cortex of roots, tubers and bulbs of plants, resulting in extensive root necrosis (Zunke, 1990; Taylor et al., 1999; Vanstone et. al., 1998) while providing avenues for secondary colonization by pathogenic microorganisms fungi and bacteria (Corbett, 1973). Their worldwide distribution, broad host ranges and interrelationships with other pests and diseases rank them among some of the most important soilborne pathogens affecting agricultural crops (Jones et al., 2013). P. crenatus has been reported in America, Asia, Europe, North America, Oceania and South and Central America; and $P$. neglectus has been reported in Africa, America, Asia, Europe, North America, Oceania and South and Central America (Castillo $\&$ Vovlas, 2007). P. crenatus and P. neglectus are found in a broad range of soil types from heavy clays to sandy soils and these two species occurs more frequently in acid than in neutral or alkaline soils. Vertical distribution of $P$. crenatus in different soil types was $70 \%$ in the top $22 \mathrm{~cm}$ and in P. neglectus $94 \%$ of specimens occur in the upper layers of soil up to $20 \mathrm{~cm}$ (Taylor and Evans, 1998) and both species are reported to be pathogenic to cereals crops and are associated with poor growth of cereals plants (Castillo \& Vovlas, 2007).

Morphological methods can be time-consuming and impractical when rapid results are required. The use of molecular diagnostic tools like PCR with species specific primers (Al-Banna et al., 2004, Mekete et. al., 2011) and sequencing of diagnostic rDNA regions in combination with phylogenetic analyses contributes to overcome 
Table 1. Primers used to amplify ribosomal DNA

\begin{tabular}{llll}
\hline Primer name & Direction & Primer sequence 5' $^{\prime}$ - 3' & Reference \\
\hline PNEG & forward & ATG AAA GTG AAC ATG TCC TC & Al-Banna et al., 2004 \\
PCR22_F & forward & AAA GCC TGA ATG CCC TGA G & Mekete et al., 2011 \\
PCR22_R & reverse & AAA TTG AAA GAG GTC GGT CGT & Mekete et al., 2011 \\
988F & forward & CTC AAA GAT TAA GCC ATG C & Holterman et al., 2006 \\
1096F & forward & GGT AAT TCT GGA GCT AAT AC & Holterman et al., 2006 \\
1912R & reverse & TTT ACG GTC AGA ACT AGG G & Holterman et al., 2006 \\
1813F & forward & CTG CGT GAG AGG TGAAAT & Holterman et al., 2006 \\
2646R & reverse & GCT ACC TTG TTA CGA CTT TT & Holterman et al., 2006 \\
D2A & forward & ACAAGT ACC GTG AGG GAAAGT TG & De Ley et al., 1999 \\
D3B & reverse & TCG GAA GGAACC AGC TAC TA & De Ley et al., 1999 \\
\hline
\end{tabular}

such a problem. The use of rDNA is potentially the most powerful method of nematode diagnosis. Ribosomal DNA (rDNA) sequence has been shown to be a reliable genetic marker for identification purposes, and a powerful tool to analyze genetic variation. The 28S D2/D3 rDNA fragment has been used frequently to characterise Pratylenchus populations (Handoo et al., 2001; Al-Banna et al., 2004; De Luca et al., 2004; Inserra et al., 2007; Subbotin et al., 2008).

Previously $P$. neglectus has been found under the rhizosphere of Brassica (Kumari, 2012) and Pratylenchus sp. has been found associated with hop plants (Cermak, 2011) in the Czech Republic, but despite the economical importance of RLN, there is a lack of knowledge about the diversity and distribution of RLN associated with cereal crops in the Czech Republic. Considering the economic significance of RLN in cereal crops a study was initiated to study the occurrence of these nematodes in the Czech Republic. Two species P. crenatus Loof, 1960 and P. neglectus (Rensch, 1924) Filipjev \& Schuurmans Stekhoven, 1941 which were found in the latest survey of cereal crops, were described here. The specific objectives of the work were: 1) to characterise $P$. crenatus and $P$. neglectus based on morphology and morphometrics; 2) to amplify these species using species-specific published primers; 3 ) to sequence two (D2/D3 expansion segment of $28 \mathrm{~S}$ and partial $18 \mathrm{~S}$ gene) regions of ribosomal DNA.

\section{Material and Methods}

Soils samples were collected from the wheat growing areas in Bohemia, Czech Republic. Soil samples were taken at a depth of $0-30 \mathrm{~cm}$ and nematodes were extracted from soil by sieving on $1 \mathrm{~mm}, 150 \mu \mathrm{m}$ and $75 \mu \mathrm{m}$ and placing the residual on $99 \mu \mathrm{m}$ and $56 \mu \mathrm{m}$ sieve on a Baermann funnel from $24-48$ hours (Brown and Boag, 1998). Nematodes for morphological study were heat killed, fixed in TAF, processed in slow glycerin process and mounted in anhydrous glycerin on slides (Courtney et al., 1955). Photomicrographs were recorded with a digital camera linked to a computer and measurements were made with the aid of imaging software (Olympus DP-soft).

For specific amplification of $P$. crenatus primer set PCR22_F+PCR22_R and for $P$. neglectus primers set PNEG+D3B were used. Primer sequences and references to the primers are given in Table 1.Total genomic DNA was extracted from single individuals with a rapid technique (Stanton et al., 1998). The PCR was performed in a $25 \mu$ l total volume containing 1 PCR bead (GE Healthcare, Buckinghamshire, UK), $20.5 \mu$ l double distilled sterile water, $2.0 \mu \mathrm{l}$ each primer $(10 \mathrm{pmol} / \mu \mathrm{l})$ (synthesized by Generi Biotech, Hradec Králové, Czech Republic), and to this $0.5 \mu \mathrm{l}$ of DNA was added as a template for PCR. A negative control (sterilized water) was included in all PCR experiments. All PCR reactions were performed on a

Table 2. NCBI accession numbers of representative individual specimen for ribosomal DNA

\begin{tabular}{lllll}
\hline Species & Locality & isolate & 18S & 28S \\
\hline P. crenatus & Chlumec & CRLN1 & KM580535 & KM580543 \\
& Chvaletice & CRLN2 & KM580536 & KM580544 \\
& Krymlov & CRLN3 & KM580537 & KM580545 \\
P. neglectus & Brandýsek & CRLN4 & KM580538 & KM580546 \\
& Kolinec & CRLN5 & KM580539 & KM580547 \\
& Kozojedy & CRLN6 & KM580540 & KM580548 \\
& Krymlov & CRLN7 & - & - \\
& Suchdol & CRLN8 & KM580541 & KM580549 \\
& Zásmuky & CRLN9 & KM580542 & KM580550 \\
\hline
\end{tabular}

- not acquired 
Table 3. Morphometrics of females of $P$.crenatus and $P$. neglectus. Measurements in $\mu \mathrm{m}$ (in form): mean \pm standard deviation (range)

\begin{tabular}{|c|c|c|}
\hline Species & P. crenatus & P. neglectus \\
\hline Locality & Chvaletice & Kolinec \\
\hline $\mathrm{n}$ & 13 & 31 \\
\hline \multirow[t]{2}{*}{$\mathrm{L}$} & $445 \pm 21$ & $494 \pm 40$ \\
\hline & $(415-483)$ & $(413-573)$ \\
\hline \multirow[t]{2}{*}{ a } & $26.8 \pm 2.30$ & $24.2 \pm 2.08$ \\
\hline & $(23.0-30.1)$ & $(19.2-27.9)$ \\
\hline \multirow[t]{2}{*}{ b } & $4.6 \pm 0.31$ & $4.25 \pm 0.36$ \\
\hline & $(4.2-5.1)$ & $(3.7-5.0)$ \\
\hline \multirow[t]{2}{*}{ c } & $19.7 \pm 1.98$ & $21.01 \pm 2.81$ \\
\hline & $(17.2-23.1)$ & $(16.0-26.7)$ \\
\hline \multirow[t]{2}{*}{ C } & $2.26 \pm 0.14$ & $2.04 \pm 0.32$ \\
\hline & $(2.00-2.50)$ & $(1.60-2.70)$ \\
\hline \multirow[t]{2}{*}{ V } & $83 \pm 1.12$ & $81 \pm 1.41$ \\
\hline & $(81-84)$ & $(78-84)$ \\
\hline \multirow[t]{2}{*}{0} & $17.5 \pm 4.58$ & $19.49 \pm 4.07$ \\
\hline & $(13.3-23.1)$ & $(12.5-26.7)$ \\
\hline \multirow[t]{2}{*}{ DGO } & $2 \pm 0.51$ & $3 \pm 0.65$ \\
\hline & $(2-3)$ & $(2-4)$ \\
\hline \multirow[t]{2}{*}{ Stylet length } & $14 \pm 0.73$ & $16 \pm 1.50$ \\
\hline & $(13-15)$ & $(14-19)$ \\
\hline \multirow[t]{2}{*}{ Metenchium length } & $6 \pm 0.63$ & $6 \pm 1.15$ \\
\hline & $(5-7)$ & $(5-9)$ \\
\hline \multirow[t]{2}{*}{ Telenchimum length } & $8 \pm 0.28$ & $10 \pm 0.77$ \\
\hline & $(7-8)$ & $(8-11)$ \\
\hline \multirow[t]{2}{*}{ m } & $40 \pm 2.67$ & $40 \pm 4.43$ \\
\hline & $(38-47)$ & $(31-50)$ \\
\hline \multirow[t]{2}{*}{ MB } & $49 \pm 1.62$ & $40 \pm 6.36$ \\
\hline & $(47-53)$ & $(31-59)$ \\
\hline \multirow[t]{2}{*}{ Excretory pore } & $69 \pm 3.37$ & $84 \pm 4.56$ \\
\hline & $(64-74)$ & $(75-94)$ \\
\hline \multirow[t]{2}{*}{ EP\%L } & $15 \pm 1.18$ & $17 \pm 0.91$ \\
\hline & $(13-17)$ & $(15-19)$ \\
\hline \multirow[t]{2}{*}{ Pharynx length } & $97 \pm 4.00$ & $117 \pm 9.07$ \\
\hline & $(91-105)$ & $(96-136)$ \\
\hline \multirow[t]{2}{*}{ Pharynx to vulva } & $270 \pm 20.35$ & $284 \pm 34$ \\
\hline & $(240-305)$ & $(219-358)$ \\
\hline \multirow[t]{2}{*}{ head to vulva } & $368 \pm 18.77$ & $401 \pm 36$ \\
\hline & $(338-400)$ & $(329-480)$ \\
\hline \multirow[t]{2}{*}{ VL/VB } & $5 \pm 0.51$ & $5 \pm 0.63$ \\
\hline & $(4-6)$ & $(4-7)$ \\
\hline \multirow[t]{2}{*}{ Vulva - anus length } & $54 \pm 4.48$ & $69 \pm 5.85$ \\
\hline & $(46-63)$ & $(59-85)$ \\
\hline \multirow[t]{2}{*}{ Tail length } & $23 \pm 2.82$ & $24 \pm 2.99$ \\
\hline & $(18-28)$ & $(19-33)$ \\
\hline Body diameter at lip region & $7 \pm 0.49$ & $8 \pm 0.58$ \\
\hline & $(6-8)$ & $(7-9)$ \\
\hline at mid body & $16 \pm 1.82$ & $20 \pm 1.59$ \\
\hline & $(13-20)$ & $(17-22)$ \\
\hline at vulva & $15 \pm 0.85$ & $18 \pm 2.07$ \\
\hline & $(13-16)$ & $(14-23)$ \\
\hline at anus & $10 \pm 1.04$ & $12 \pm 1.37$ \\
\hline & $(9-12)$ & $(10-15)$ \\
\hline
\end{tabular}


DNA Engine PTC-1148 thermal cycler (Bio-Rad). The DNA was subjected to a PCR with the following specifications: first denaturation for $3 \mathrm{~min}$ at $95^{\circ} \mathrm{C}, 41 \mathrm{cycles}$ with $30 \mathrm{~s}$ at $95^{\circ} \mathrm{C}, 30 \mathrm{~s}$ at $62^{\circ} \mathrm{C}$, $30 \mathrm{~s}$ at $72{ }^{\circ} \mathrm{C}$ and final extension at $72{ }^{\circ} \mathrm{C}$ for $10 \mathrm{~min}$. An aliquot (6ul) of each amplification reaction was mixed with $1.5 \mu \mathrm{l}$ of $6 \mathrm{x}$ loading dye (Fermentas, MBI) and electrophoresed in high resolution $1.5 \%$ agarose gel and run in TAE (Tris-Acetate-EDTA) buffer. The bands were visualized and photographed under UV (312 nm) after syber safe $(1 \mu \mathrm{g} / \mathrm{ml})$ binding to the DNA fragments. A 100 base pair marker (Fermentas) was included on gel.

Additionally $18 \mathrm{~S}$ gene and D2/D3 expansion segment of $28 \mathrm{~S}$ gene of ribosomal DNA was amplified. 18S was amplified in two overlapping fragments and primer combination was $988 \mathrm{~F}+1912 \mathrm{R}$ or $1096 \mathrm{~F}+1912 \mathrm{R}$ for the first fragment and $1813 \mathrm{~F}+2646 \mathrm{R}$ for the second fragment. D2/D3 expansion segments of $28 \mathrm{~S}$ gene were amplified using D2A+D3B primers. PCR reactions were performed as described above. The cycling conditions were: first denaturation for 3 min at $94^{\circ} \mathrm{C}, 40$ cycles with $30 \mathrm{~s}$ at $94^{\circ} \mathrm{C}, 30 \mathrm{~s}$ at $55^{\circ} \mathrm{C}, 30$ $\mathrm{s}$ at $72{ }^{\circ} \mathrm{C}$ and a final elongation step was run at $72{ }^{\circ} \mathrm{C}$ for $10 \mathrm{~min}$.
DNA was purified using High Pure Product Purification kit (Roche Diagnostics $\mathrm{GmbH}$, Manheim, Germany) or by gel extraction kit (Qiagen) and directly sequenced in both directions (Macrogen, Netherlands). Sequencher ${ }^{\mathrm{TM}} 4.8$ (Genes Codes. Corp., Ann Arbor, MI, USA) software was used to assemble and view sequences and check for base-calling errors. Sequences were deposited in Genbank and their accession numbers are given in Table 2.

\section{Results and Discussion}

A survey has been started in the Czech Republic to study plant parasitic nematodes associated with cereals crops. In the first survey 12 wheat growing localities were surveyed for the presence of plant parasitic nematodes and eight localities were found positive for the presence of Pratylenchus spp. Two localities were found positive for $P$. crenatus and five for $P$. neglectus. At one locality (Krymlov) both species were present. At Kolinec P. neglectus occurred with one more Pratylenchus sp. which will be described in a different work.

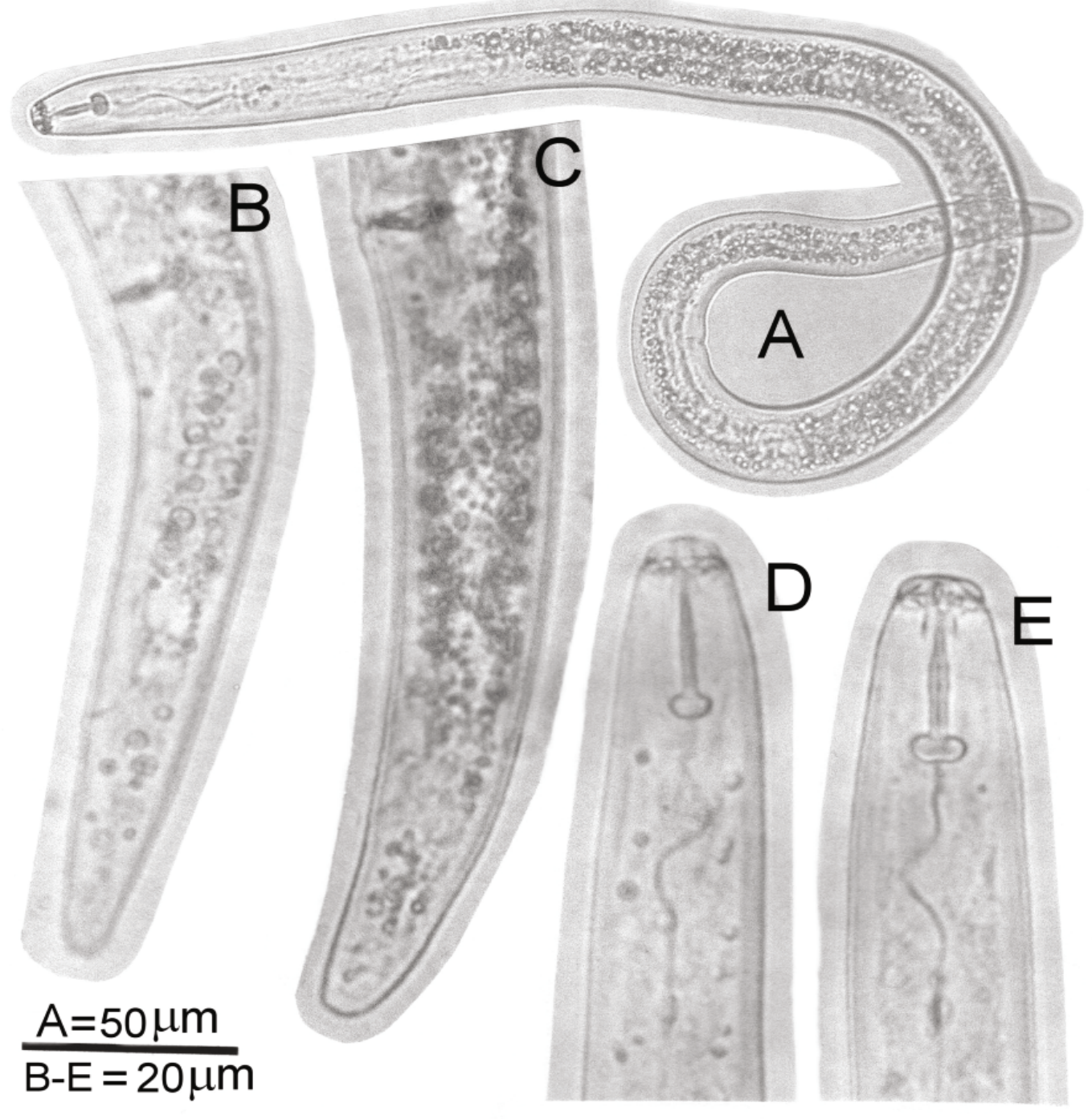

Fig. 1. Photomicrographs of females of $P$. crenatus (B: posterior region; $\mathrm{D}$ : anterior region) and $P$. neglectus (A: entire female; C: posterior region; E: anterior region) 

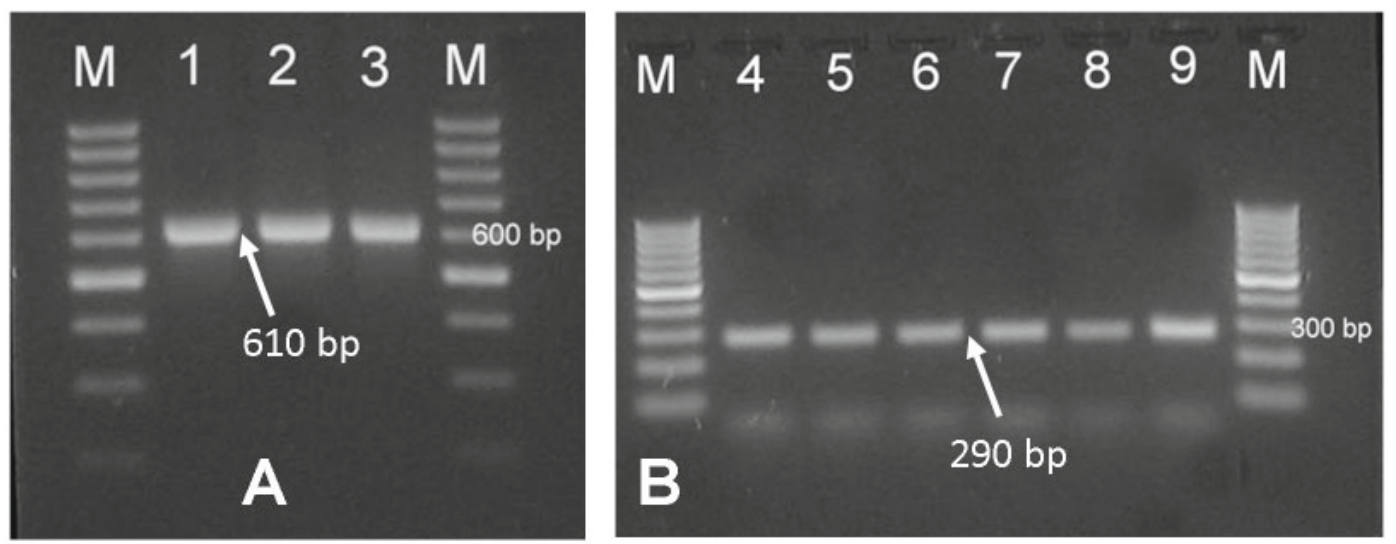

Fig. 2. Electrophoresis of the amplified products from single individual nematodes. A: $P$. crenatus 610bp, lane 1: Chlumec; lane 2: Chvaletice; lane 3: Krymlov. B: $P$. neglectus $290 \mathrm{bp}$, lane 4: Brandýsek; lane 5: Kolinec; lane 6: Kozojezdy; lane 7: Krymlov; lane 8: Suchdol; lane 9: Zásmuky and lane M:100 bp DNA ladder (Fermentas)

Morphometrics of females of $P$. crenatus and $P$. neglectus are given in Table 3 and photomicrographs are presented on Fig.1. Morphometrics of females of $P$. crenatus is within the minimum and maximum ranges given by Castillo and Vovlas (2007) except radio ' $b$ ' which is smaller $4.2-5.1$ vs $4.9-7.9$. All morphometrics of $P$. neglectus are within the minimum and maximum ranges given by Castillo and Vovlas (2007) and Fayazi et al. (2012) except ratio 'm' where minimum value is smaller $31-50$ vs $40.8-48.5$ (Fayazi et al., 2012). P. crenatus stylet knob width is $3 \pm 0.51$ ( $3-4)$ um where $P$. neglectus stylet width is $5 \pm 0.6(4-6) \mu \mathrm{m}$; $P$. crenatus tail tip is crenate where as $P$. neglectus tail tip is without annulation.

In recent years it has become a standard to identify species on the basis of morphological and molecular data with more emphasis on molecular work. Therefore in this work species specific PCR was performed to confirm the morphological identification of the both species using published primers (Al-Banna et al.,2004; Mekete et al., 2011). Moreover $18 \mathrm{~S}$ and $28 \mathrm{~S}$ partial genes of ribosomal DNA have been analyzed and compared. PCR with species specific primers set PCR22_F+PCR22_R for $P$. crenatus and primers set PNEG+D3B_R for $P$. neglectus yielded a fragment of approximately 610 bp and 290 bp respectively (Fig.2). No PCR products were obtained in the negative control lacking DNA template or in the negative control containing DNA of Aphelenchus, Bitylenchus, Boleodorus and Helicotylenchus (data not shown).

Sequence analysis of partial 18S gene of $P$. crenatus (accession numbers KM580535, KM5080536, KM580537) among the three Czech populations did not reveal any variation. $18 \mathrm{~S}$ gene differs from other accession numbers AB905287, AB905288, AB905289, AB905290 (Kushida and Kondo, 2015) AY284610 (Holterman et al., 2006), EU130800 (Subbotin et al., 2008), EU669920, EU669921, EU669922 (Holterman et al., 2009) by $0.14-1.66 \%$ and these twelve sequences (KM580535-KM580537, AB905287AB905290, AY284610, EU130800, EU669920- EU669922) differ from each other $0-2.34 \%$. This sequence variability is too high for conservative $18 \mathrm{~S}$ gene therefore one should be cautious when comparing $18 \mathrm{~S}$ sequences of $P$. crenatus. In this study $18 \mathrm{~S}$ gene and D2/D3 expansion segments and species-specific PCR were amplified from the same genomic DNA.

Sequence analysis of D2/D3 expansion segments of $P$. crenatus (accession numbers KM580543, KM580544, KM580545) among the three Czech populations also did not reveal any variation. The sequences of $\mathrm{D} 2 / \mathrm{D} 3$ of $P$. crenatus differs from published sequences EU130852, EU130853 (Subbotin et al., 2008), HM921215 (Mekete et al., 2011) by 0.45 to $1.36 \%$ and these six sequences (KM580543-KM580545, EU130852, EU130853, HM921215) varied by $0-1.82 \%$.

Sequences of $18 S$ gene of $P$. neglectus among five populations (accession numbers KM580538-KM580542) from the Czech Republic differ by $0-0.14 \%$. These sequences differs from other sequences AB905298-AB905303 (Kushida and Kondo, 2015), EU130801, EU130802 (Subbotin et al., 2008), EU669923, EU669924 (Holterman et al., 2009), JQ303332 (Kumari, 2012), KC875378 (Rybarczyk-Mydłowska et al., 2015) from NCBI by $0-0.56 \%$. All these 17 (KM580538-KM580542, AB905298-AB905303, EU130801, EU130802, EU669923, EU669924, JQ303332, KC875378) sequences differ from each other $0-0.70 \%$.

Sequence analysis of D2/D3 expansion segments of $P$. neglectus (accession numbers KM580546-KM580550) differ by 0.17 $-0.50 \%$. The sequences of D2/D3 differs from other accession numbers EU130854, EU130855 (Subbotin et al., 2008), HM469438 (unpublished), JQ303333 (Kumari, 2012), JX046968, JX046969 (Wang et al., 2012), JX261946, JX261947, JX261951 (Majd Taheri et al., 2013) by $0.17-1.51 \%$ and these 14 sequences (KM580546KM580550, EU130854, EU130855, HM469438, JQ303333, JX046968, JX046969, JX261946, JX261947, JX261951) varied by $0.17-2.01 \%$.

The aim of this study was to identify two Pratylenchus species associated with wheat crop in the Czech Republic. There are over 60 named species of root lesion nematode (Pratylenchus spp.) which are distributed worldwide (Jones et al., 2013). Because each species differs in host preference, it is essential that they be correctly identified. The ability to identify RLN responsible for crop damage is a fundament of plant nematology and for implementing adequate management strategies. It is important to distinguish between the different species of nematodes occurring in a specific region associated with a specific crop in order to estimate the extent of the damage to the crop and to make decisions on appropriate control measures, therefore morphological and molecular means were used to 
identify the two Pratylenchus species (P. crenatus and $P$. neglectus) in the Czech Republic and the results confirmed their identification.

\section{Acknowledgements}

The work was supported by the National Agency of Agriculture Research of the Czech Republic, Project number QJ1230159.

\section{References}

Al-Banna, L., Ploeg, A.T., Williamson, V.M., Kaloshian, I. (2004): Discrimination of six Pratylenchus species using PCR and species-specific primers. J. Nematol., 36: 142 - 146

Brown, D.J. F, BoAg, B. (1988): An examination of methods used to extract virus-vector nematodes (Nematoda: Longidoridae and Trichodoridae) from soil samples. Nematol. Mediterr., 16: 93-99 Castillo, P., Vovlas, N. (2007): Pratylenchus (Nematoda, Pratylenchidae): Diagnosis, biology, pathogenicity and management. Nematol. Monogr. Perspect., 6: 1 - 530

ČERMÁK, V., GaAr, V., HÁnĚL, L., ŠIROKÁ, K. (2011): Composition and vertical distribution of free living and plant parasitic nematodes in hop gardens in the Czech Republic. Helminthologia, 48: 124 136. DOI: 10.2478/s11687-011-0017-3

CoRbetT, D.C.M. (1973): Pratylenchus penetrans. CIH Descriptions of plant-parasitic nematodes, Set 2, No. 25.

Courtney, W.D., Polley, D., Miller, V.L. (1955): TAF, an improved fixative in nematode technique. Plant Dis. Rep., 39: 570-571

De Ley, P., Félix, M.A., Frisse, L.M., Nadler, S.A., Sternberg, P.W., THOMAS, W.K. (1999): Molecular and morphological characterisation of two reproductively isolated species with mirror-image anatomy (Nematoda: Cephalobidae). Nematology, 1: 591 - 612

De Luca, F., Faneelli, E., Di Vito, M., Reyss, A., De Giorgi, C. (2004): Comparison of the sequences of the D3 expansion of $26 S$ ribosomal genes reveals different degrees of heterogeneity in different population and species of Pratylenchus from the Mediterranean region. Eur. J. PI. Path., 110: 949 - 957. DOI: 10.1007/ s10658-004-0813-4

Fayazi, F., Farokhi-Nejd, R., Ahmadi, A.R., Memarl, H.R., Bahmani, Z. (2012): Molecular and morphometric identification of $P$. thornei and P. neglectus in southwest of Iran. J. Plant Pathol. Microb., 3: 123. DOI: 10.4172/2157-7471.1000123

Handoo, Z.A., Carta, L.K., Skantar, A.M. (2001): Morphological and molecular characterization of Pratylenchus arlingtoni $\mathrm{n}$. sp., $P$. convallariae and $P$. fallax (Nematoda: Pratylenchidae). Nematology, 3: 607 - 618. DOI: 10.1163/156854101753389220

Holterman, M., Karssen, G., van den Elsen, S., van Megen, H., BAKKER, J., HeLder, J. (2009): Small subunit rDNA-based phylogeny of the Tylenchida sheds light on relationships among some high-impact plant-parasitic nematodes and the evolution of plant feeding. Phytopathology, 99: 227 - 235. DOI: 10.1094/PHYTO-99-3-0227 Holterman, M., van der Wurff, A., van Den Elsen, S., van Megen, H., Bongers, T., Holovachov, O., Bakker, J., Helder, J. (2006): Phylum-wide analysis of SSU rDNA reveals deep phylogenetic relationships among nematodes and accelerated evolution toward crown clades. Mol. Biol. Evol., 23: 1792 - 1800. DOI: 10.1093/ $\mathrm{molbev/mls044}$
Inserra, R.N., Troccoli, A., Gozel, U., Bernard, E., Dunn, D., Duncan, W. (2007): Pratylenchus hippeastri n. sp. (Nematoda: Pratylenchidae) from amaryllis in Florida with notes on $P$. scribneri and $P$. hexincisus. Nematology, 9: 25 - 42. DOI: 10.1163/156854107779969754

Jones, J.T., Haegeman, A., Danchin, E.G.J, Gaur, H.S., Helder, J., Jones, M.G. K., KiKuchi, T, Manzanilla-López, R., Palomares-Rius, J.E., Wesemael, W.M.L., Perry, R.N. (2013): Top 10 plant-parasitic nematodes in molecular plant pathology. Mol. Plant Pathol., 14 (9): 946 - 961. DOI: $10.1111 / \mathrm{mpp} .12057$

Kumari, S. (2012): Pratylenchus neglectus (Nematoda: Aphelenchidae) under the rhizosphere of Brassica napus. Helminthologia, 49: 92 - 95. DOI: 10.2478/s11687-012-0019-9

KushidA, A., Kondo, N. (2015): Simultaneous detection and discrimination of Pratylenchus and Meloidogyne species in Japanese fields using group-specific primers and denaturing gradient gel electrophoresis. J. Gen. Plant Pathol., 81: 687 - 693. DOI: 10.1007/s10327-014-0572-9

Majd Taheri, Z., Tanha Maafi, Z., Subbotin, S.A., Pourjam, E., EsKANDARI, A. (2013): Molecular and phylogenetic studies on Pratylenchidae from Iran with additional data on Pratylenchus delattrei, Pratylenchoides alkani and two unknown species of Hirschmanniella and Pratylenchus. Nematology, 15: 633 - 651. DOI: 10.1163/ 15685411-00002707

Mekete, T., Reynolds, K., Lopez-Nicora, H.D., Gray, M.E., Niblack, T.L. (2011): Distribution and diversity of root-lession nematode (Pratylenchus spp.) associated with Miscanthus $\times$ giganteus and Panicum virgatum used for biofuels, and species identification in a multiplex polymerase chain reaction. Nematology, 13 (6): 673 686. DOI: $10.1163 / 138855410 X 538153$

Nicol, J., RivoAl, R., TaYlor, S., Zaharieva, M. (2004): Global importance of cyst (Heterodera spp.) and lesion nematodes (Pratylenchus spp.) on cereals: distribution, yield loss, use of host resistance and integration of molecular tools. Nematol. Monogr. Perspect., 2: 233 - 251

RIVOAL, R., Cook, R. (1993): Nematode pests of cereals. In: Evans, K., Trudgill, D.L., Webster, J.M. (Eds) Plant Parasitic Nematodes in Temperate Agriculture. CAB International, Wallingford, England, pp. $259-303$

Rybarczyk-Myd owska K., van Megen H., van den Elsen S., Mooyman P., Karssen G., Bakker, J., Helder, J. (2014): Both SSU rDNA and RNA polymerase II data recognise that root-knot nematodes arose from migratory Pratylenchidae, but probably not from one of the economically high-impact lesion nematodes. Nematology, 16: 125 - 136. DOI: 10.1163/15685411-00002750

Stanton, J.M., McNicol, C.D., Steele, V. (1998): Non-manual lysis of second-stage Meloidogyne juveniles for identification of pure and mixed samples based on the polymerase chain reaction. Australas. Plant Pathol., 27: 112 - 115. DOI: 10.1071/AP98014

Subbotin, S.A., Ragsdale, E.J., Mullens, T., Roberts, P.A., MunDo-Ocampo, M., BaldWIN, J.G. (2008): A phylogenetic framework for root lesion nematodes of the genus Pratylenchus (Nematoda): Evidence from $18 \mathrm{~S}$ and D2-D3 expansion segments of 28S ribosomal RNA genes and morphological characters. Mol. Phylogenet. Evol., 48: 491 - 505. DOI: 10.1016/j.ympev.2008.04.028

Subbotin, S.A., Ragsdale, E.J., Mullens, T., Roberts, P.A., Mun- 
DO-OCAMPO, M., BaldWIN, J.G. (2008): A phylogenetic framework for root lesion nematodes of the genus Pratylenchus (Nematoda): Evidence from $18 \mathrm{~S}$ and D2-D3 expansion segments of $28 \mathrm{~S}$ ribosomal RNA genes and morphological characters. Mol. Phylogenet. Evol., 48: 491 - 505. DOl: 10.1016/j.ympev.2008.04.028

TAYLOR, S.P., Evans, M.L (1998): Vertical and horizontal distribution of and soil sampling for root lesion nematodes (Pratylenchus neglectus and P. thornei) in South Australia. Australas. Plant Pathol., 27: 90 - 96. DOI: 10.1071/AP98011

Taylor, S.P., Vanstone, V.A., Ware, A.H., McKay, A.C., Szot, D., Russ, M.H. (1999): Measuring yield loss in cereals caused by root lesion nematodes (Pratylenchus neglectus and $P$. thornei) with and without nematicide. Aust. J. Agric. Res., 50: 617 - 622. DOI: 10.1071/A98103
Vanstone, V.A., Rathuen, A.J., Ware, A.H., Wheeler, R.D. (1998): Relationship between root lesion nematodes (Pratylenchus neglectus and $P$. thornei) and performance of wheat varieties. Aust. J. Exp. Agr., 38: 181 - 188. DOI: 10.1071/EA97109

Wang, J.C., Huang, G.M., Wel, Y.D., LiaO, F., Zhang, R.F., Guo, J.Z., LiU, P., Zhang, Y.J., Luo, J.F. (2012): Phylogenetic analysis of Pratylenchus (Nematoda: Pratylenchidae based on ribosomal internal transcribed spacers (ITS) and D2/D3 expansion segments of $28 \mathrm{~S}$ rRNA gene. Acta Zootax. Sin., 4: 687 - 694

ZUNKE, U. (1990): Ectoparasitic feeding behavior of the root lesion nematode, Pratylenchus penetrans, on root hairs of different host plants. Rev. Nématol., 13: 331 - 337 